\title{
Necromancy or life support? Libraries, democracy and the concerned intellectual.
}

\author{
Alex Byrne
}

\section{Word Count: 5196}

Keywords: human rights, intellectuals, democracy, intellectual freedom, libraries, IFLA.

Biographical Note: Alex Byrne chairs the Committee on Free Access to Information and Freedom of Expression (FAIFE - http://www.faife.dk) and is a member of the Governing Board of the International Federation of Library Associations and Institutions (IFLA http://www.ifla.org). He is the University Librarian and a Deputy Chair of the Academic Board at the University of Technology, Sydney in Australia where he can be contacted on Tel +61 29514 3332, Fax +61 29514 3331, alex.byrne@uts.edu.au. An earlier version of this paper was presented on my behalf by Ms Cai Wei at a Symposium, "Death of the Concerned Intellectual?” Institute of International Studies, University of Technology, Sydney on 25-26 March 2002.

\begin{abstract}
Aims to examine the rôles of libraries and their development. Their part in fostering and supporting intellectuals in contemporary societies is discussed with particular emphasis on free access to information and freedom of expression. From the nineteenth century, libraries became recognised as necessary to society. In recent years. Libraries have increasingly been seen an instrument for the development and maintenance of a democratic society which offers the individual access to a wide and varied range or knowledge, ideas and opinions. The ubiquity of the Internet and other media and their promise of universal access to information 'regardless of frontiers' have reinforced the democracy paradigm. In fulfilling a function of sustaining the discourse of concerned intellectuals libraries demonstrate their importance to humanity.
\end{abstract}

The last quarter of the nineteenth century saw momentous changes in libraries reflecting the rapid growth in scientific and technological knowledge and the consequent societal change in Europe and North America. Industrialisation had required the growing concentration of workers in towns and cities. Gas lighting, followed by arc lighting and then electric lighting had made it possible for conurbations to operate through the night. The bright carbide light had replaced Thoreau's candle and the solitary reader was joined by thousands of all classes seeking to improve themselves. In this striving for knowledge, the library began to be seen as an instrument for the "readers", to enable "a poor student to have the same means of indulging his learned curiosity, of following his rational pursuits, of consulting the same authorities, of fathoming the most intricate inquiry as the richest man in the kingdom, as far as books go" (Panizzi, 1836). 
Thus, libraries for the first time became recognised as necessary to society. National libraries began to play a more active part in the scientific and cultural life of their countries while continuing their primary purpose as depository libraries. But this was not sufficient; the existing learned libraries could not satisfy the ever-growing need for knowledge and information. A new type of library came into being, the public library (IFLA, 1963: 1-2). The UK Public Libraries Act of 1850 outlined the expectations for this new type of library which were illustrated by the pioneering Manchester Public Library established in 1852 (Munford, 1976: 11). Its model was followed elsewhere although the development of public libraries in most countries occurred predominantly in the twentieth century (IFLA, 1963: 1-2). Public libraries were promoted by concerned citizens, municipal authorities and, especially, the Carnegie Corporation which funded library buildings, known as 'Carnegie libraries', in many countries (Anderson, 1970). They gradually replaced the subscription libraries to which men, and sometimes women, of comfortable means had belonged. Availability to all, irrespective of financial capacity, became a key goal of public library services.

These nineteenth century developments had been prefigured in earlier times. The first university library was established at the Sorbonne which was founded in 1257 and Louis IX set up the earliest public library in the Sainte Chapelle at about the same time. Town libraries, often located in churches, were founded in many German cities in the fifteenth century (Hobson, 1970: 12). However, clerics and men of learning were in practice the only people who could use those early 'public' libraries. The revolutionary concept of the 'library for the public' had to await the nineteenth century development of secular universities, schools and public libraries.

\section{The treasure house}

Before that dramatic change, libraries had been regarded primarily as storehouses of knowledge. The Biblioteca Capitolare in Verona for example preserved the Younger Pliny's Letters and the poems of Tibullus and Catullus as well as early religious works from the sixth century onwards (Hobson, 1970: 17ff). Many works were preserved even when considered unacceptable by church, state or library authorities. The creation of the great libraries was driven by acquisitiveness. Some, including the Museion of Alexandria, aimed at universality as their librarians attempted to collect without limit, infamously using force to obtain all manuscripts carried by seafarers as well as those taken from tributary states (Kesting, 1985). Less hostile methods included soliciting copies from other libraries, borrowing manuscripts to copy in scriptoria or visiting other libraries to make copies, traditions which were continued by monastic libraries until printing made them redundant.

\section{Just in case to just in time}

Contemporary successors to the great royal and ecclesiastical libraries are national libraries and the libraries of major universities. Both, however, have abandoned aspirations to universality. Librarians have long recognised that no modern library can aspire to be comprehensive except in a very small number of the most tightly defined fields. Whatever its past possibility, the continual proliferation of media and titles, and the ceaselessly spiralling costs of publications, particularly of scholarly journals, has ensured that such a goal must be illusory. 
There is increasing emphasis on access to information resources, and to the information itself, rather than acquisition of the resources. It is an approach which has been labelled access to information just in time to meet the client's needs rather than acquisition just in case a client might need the resource (Nichols and Smith, 2001). The reorientation to access started with Panizzi at the British Museum who was challenged at the 1847 Royal Commission by Carlyle, who had been unable to fine the collections of French Revolutionary tracts in the catalogue. “'For all practical purposes,' he complained, ' this collection of ours might as well have been locked up in water-tight chests and sunk on the Dogger Bank as put in the British Museum.' ...” (Miller, 1988: 178-179). Panizzi, somewhat grudgingly, acknowledged Carlyle’s suggestion that there should be members of the staff specially detailed to whom readers might go for information and assistance, a reform that had to wait for nearly a century before it was fully implemented.

The general public has gradually recognised the evolving rôle of libraries, the transformation with which librarians have been engaging for several decades. Speculating on the library in the twenty-first century, Molholt (1993) noted that "We need to plan for a change in emphasis from being the keepers of the book to being guides through the universe of knowledge". This sea change has been demonstrated through the innovations introduced over the last century. They have included open physical access to collections, systematised cataloguing and classification of all holdings using internationally recognised and interchangeable data, online access to catalogues, distributed access to databases and the digital library. The dramatic improvements in access available via full text searching, the world wide web, electronic delivery and so on have now made it possible to renew the vision of the universal library. Rather than a vast Alexandrian storehouse, the universal library is now achievable through library facilitated access to all knowledge.

\section{From people's university to information literacy}

The IFLA/Unesco Guidelines (IFLA Section of Public Libraries, 2001) define the public library as an organisation established, supported and funded by the community which provides access to knowledge, information and works of the imagination to all members of the community. Its purposes include education, information, assisting personal development, services to children and young people, providing a focus for cultural development, and offering a public meeting place. The Guidelines note that public libraries have "an important rôle in the development and maintenance of a democratic society by giving the individual access to a wide and varied range or knowledge, ideas and opinions” (Ibid: 2). This is more utilitarian than the lyricism of the 1973 IFLA Standards for public libraries which posits:

\section{A democratic institution for education, culture and information}

The Public Library is a practical demonstration of democracy's faith in universal education as a continuing and lifelong process, in the appreciation of the achievement of humanity in knowledge and culture.

The Public Library is the principal means whereby the record of man's thoughts and ideas and the expression of his creative imagination are made freely available to all (IFLA Section of Public Libraries, 1973: 13-14). 
The public library is thus positioned as the wellspring of education and enlightenment. It offers children enjoyment and opportunities to develop as members of society. It supports students enrolled in educational institutions and those educating themselves. Businesses can locate information to support their activities. The sight impaired and those with other disabilities can obtain specialised services. And all members of the community can find entertainment through books, magazines, audio and video recordings, and increasingly Internet services. It informs, educates and entertains the community. In that tradition, the current focus in librarianship on "information literacy", in public libraries as well as educational libraries, adds a responsibility to assist library clients to develop the skills to access information. This pedagogical function joins the previous rôle $\mathrm{s}$ of accumulating information resources, organising and providing access to information resources, providing access to information and offering assistance.

The positivistic view of the library's agency supports its claimed rôle as an instrument of democracy. It is a relatively new rôle for libraries, which took its current form as Nazi German forces occupied Europe. American librarianship found a new social purpose and a means to justify its standing as a profession by making libraries' collections of cultural and intellectual property serve democratic values (Robbins, 1996: 2). A progressive change from censoriously dictating what readers should read to advocacy of freedom to read had created a professional climate which was ready to accept and celebrate the extended rôle of libraries in the United States (Geller, 1984). American librarians shared American intellectuals growing support for pluralist democracy with its emphasis on openness, diversity and tolerance (Booth Fowler, 1978). Libraries thus contributed to a Gramscian hegemonic project of building pluralist democracy (Robbins, 1996: 2), serving as an instrument for the reproduction of democratic values. It was given form with the ALA's adoption of The Library's Bill of Rights (American Library Association, 1939). That landmark declaration viewed the library as "an institution to educate for democratic living” which should practice non-discriminatory selection policies, acquire materials reflecting all sides of questions, and accommodate discussion on public issues. Its support for free speech anticipated the Atlantic Charter and Universal Declaration of Human Rights.

However, the rôle of libraries as political instruments for reproduction had been recognised for at least half a century previously. Libraries have been considered to hold a place in revolutionary struggle in Russia, for example, where illegal workers' libraries were organised during the 1870's. A library of Marxist and illegal literature existed from 1894 to 1895 in association with the St Petersburg Union of Struggle for the Liberation of the Working Class, which was founded by Lenin. Later, Lenin and the Bolsheviks created party libraries. Lenin "regarded libraries as social institutions, and even before the Revolution he put forth the demand that they be made accessible to the masses". (Kanevskii, 1973: 710). The purpose of libraries under the Soviet system was to "facilitate the mobilization of the working masses ... [and] actively guide reading for communist education and the raising of the cultural level of the masses. ... The basic characteristics of Soviet popular libraries are the selection and promotion among a broad range of readers of literature that facilitates the mastery of MarxistLeninist theory and political, occupational, and general educational knowledge; activity oriented toward all groups of readers; and use of the most active and effective methods for propaganda of books and guidance of reading.” (Ibid: 707-708).

\section{National identity}


Especially in universities, libraries have played an important part in the construction of institutional identity. Their buildings are generally centrally located on university campuses and often striking in design. Images of the buildings are frequently used to symbolise the institution. Libraries in schools, research institutions, legal offices and other organisations can play a similar rôle but usually in more muted fashion.

However, it is national libraries which most strikingly demonstrate the importance of libraries in identify formation. From contributing to revolutionary struggle to creating great collections of national heritage housed in symbolic buildings, such as the new Bibliothèque Nationale site François Mitterrand in Paris, national libraries are considered to both strengthen and represent the nation. Generally established by the state, national libraries are one of the major institutions, along with parliaments, courts and museums, which collectively signal the substance of a nation-state.

But, because of their responsibility for the preservation of cultural and documentary heritage, and the concomitant consecration of that heritage through recording and communicating it, national libraries have a particularly important part to play in the construction of national and state identity. It is a rôle which is functional in providing documentary testimony to the history and legitimacy of the nation-state but also symbolic. Despite their establishment and support by the state, national libraries tend rather to identify and be identified with the nation and its historical and linguistic traditions. Thus the national identity expressed through a national library may be synonymous with the identity accepted and celebrated by the state. Or it might represent only one national identity in a plural state, generally the dominant identity. Other national identities in a plural state may seek their expression through other libraries which better represent their traditions and are often the major regional or university library in the region in which that nation may be dominant, as in Catalunia.

Within an explicitly ideological context, the Lenin Library ${ }^{1}$ was charged "to promote Soviet society's economic, socio-political and spiritual progress; to educate the working people in the spirit of the norms and principles of socialism; to promote the mutual enrichment of national cultures of the peoples of the USSR; to promote cultural relations with foreign countries through the organization of the public use of the books and other materials constituting its stock" (State Lenin Library of the USSR, 1987). This is a markedly instrumental rôle, combining educative and cultural priorities, but also embodies a nationbuilding responsibility. The Library was expected to promote "socio-political and spiritual progress" not only by access to its resources but by its very existence.

While the creation of libraries of stature certainly has practical benefits in the support that they offer to education, research, government and community interests, its powerful symbolic value is perhaps more important. As Said (1984: 169) has noted, the foundation of national institutions such as libraries and universities is integral to projects that attempt to assemble a nation out of exile, as it has been for Jews and Palestinians in the twentieth century. Together with constructing a national history, and reviving an ancient language, such institutions offer a concrete realisation of national identity. As a banner over the entrance to the national museum of Afghanistan proclaimed within days of the expulsion of the Taliban regime from Kabul, “ A nation stays alive when its culture stays alive” (Steen, 2001).

\footnotetext{
${ }^{1}$ Now the Russian State Library, it was founded in 1862 as Moscow’s first free public library, the Rumiantsev Library, and became the Lenin Library after the October Revolution.
} 
It is an all too common challenge faced by nations and states to re-establish culture, language and history after war, domination and destruction. The destruction of libraries in Laos, Cambodia (Sturges and Rosenberg, 1999) and Kosova (Frederiksen and Bakken, 2000) symbolically destroyed a culture. In Kosova it started with the harassment of library staff. In Cambodia, it was an element of 'Year Zero' marking the beginning of the age of creation of a new social order. The reconstruction of libraries in those states conversely represents a return to order and the construction of a new state based on a conception of national identity based on national heritage. That conception will be selected to support the new regime's aims. For example, in the new nation of Timor Loro'sae, a national identity is being constructed around the almost 500 year narrative from the location by Portuguese seafarers of the island which was famous for its sandalwood. The emphasis on the Portuguese colonial history and scant mention of the earlier Javanese and Chinese references to the island links the new nation to European roots rather than its regional connections (Gunn, 1999).

Subsumed in these formulations about the rôles of libraries in the expression of national identity, as Canovan (1996: 16-26) has commented about political philosophy, is a tendency to accept without question nation-states and their boundaries and the bonds which unify them. Canovan castigates political theorists for this assumption that communal solidarity needs to be national. She offers two ways out of the difficulty. Some argue that states have become sufficiently self-sustaining to no longer need national identity for cohesion (Parekh, 1995). Others suggest that 'constitutional patriotism' is now sufficient to ensure that a state is peaceful, cohesive and powerful (Habermas, 1990; Canovan, 2000). Libraries, and especially national libraries and similar institutions, can give tangible expression to 'constitutional patriotism' as has been demonstrated by the Treasures from the World's Great Libraries exhibition which was presented in celebration of the centenary of Australia's federation and the creation of the National Library of Australia (National Library of Australia, 2001) ${ }^{2}$.

Thus, the separation of the desire for a peaceful and prosperous state from conceptions of national identity conversely demonstrates that the search to express national identity can run counter to the peace of the polity. The self-governing state needs to be cohesive to have the power to offer its citizens security. Consequently, secession by any element is undesirable and to be viewed as an extreme measure (Miller, 1995) which introduces the "perverse incentive" for nationalists to heighten any sense of difference, to force the population of the state to choose sides and to create or exacerbate enmity (Canovan, 2001; Beiner, 1999: 161; Ignatieff, 1994). It was this drive that stimulated the decade long harassment of librarians, removal of library materials and eventual destruction of collections in Kosova (Frederiksen and Bakken, 2001). The justification of territorial claims demanded that Albanian and Serbian identities be distinguished.

\section{Library paradigms and democracy}

The Carnegie Corporation's library initiative to fund the creation of public libraries was motivated by steel magnate Andrew Carnegie's personal experience of rising from poverty to great wealth through self education. It assisted the repositioning of the public library as the 'people's university', supporting both formal and self education through access to the world

\footnotetext{
${ }^{2}$ And emphasized by the National Archives of Australia touring exhibition in celebration of the centenary of the Australian federation, Belonging - A Century Celebrated National Archives of Australia, National Library of Australia, State Library of New South Wales and State Library of Victoria (2001) Belonging - A Century Celebrated. http://www.belonging.org/misc-pages/text.html..
} 
of knowledge. The social benefits of education were to be obtained via advantages gained by individuals through the use of public libraries to broaden their knowledge.

The democracy paradigm for libraries extended this education paradigm by explicitly locating the library as "an institution to educate for democratic living". It was considered to exemplify democratic values in being 'open to all' and designed to accommodate a plurality of ideas and views - an aim to achieve universality in clientele and opinion. As an exemplar of democratic values in its construction and operation it could be a vehicle for their reproduction throughout the community. The attainment of high standards of library service was portrayed as an instrument for social mobility for individuals and nations. The librarian added disinterested supporter of cultural pluralism, individual autonomy and client privilege to the range of subject oriented, technical and educational skills previously expected in professional practice. The revolutionary model of libraries was echoed in the expectation that libraries would be instruments for social change through the reproduction of values but the deliberate commitment to pluralism and diversity of opinion mitigated against supporting a specific political agenda.

The ubiquity of the Internet and other media and their promise of universal access to information 'regardless of frontiers' have reinforced the democracy paradigm. Despotic governments now find it very difficult to keep out unwelcome or seditious ideas and opinions as well as independent information on such issues as health and economic strength. The Chinese government has tried to suppress accurate statistics on the real rates of HIV infection but it has been circulated (World Health Organization, 2002). The impotence of contemporary authoritarian governments stands in contrast to the earlier capacity of Chairman Mao and Comrade Stalin to limit news of the horrifying famines suffered by their peoples (Becker, 1998).

Free access to information which governments would restrict, and its counterpart freedom of expression, are more readily associated with the mass media than with libraries. Indeed, journalists and their colleagues are more visible and more likely to suffer personally in pursuing their professional responsibilities than librarians. This has been amply documented through the work of Index on Censorship, Article 19, IFEX and many smaller media rights organisations. While journalists take justifiable pride in investigating matters of public moment, the results of their work would be ephemeral if it was not for the archived records maintained in libraries. Libraries enable the public, and journalists themselves, to refer back to controversies, check facts, compare reports. Without librarians 'keeping the record', it would be impossible to retrieve histories, statistics and other information as well as ideas and opinions which may be unacceptable at particular times.

'Keeping the record' can be a form of passive resistance which weakens the foundations of despotic regimes. As mentioned in the previous chapter, the manuscripts of murdered Russian writers were often preserved in the Lubyanka (Bourdieu, 1986: 467) and in the Lenin Library (Genevieva, 1999). Sometimes the resources need to be out of the country as, for example, in the reconstruction of the national library of Cambodia which depended so vitally on the assistance of libraries in the Soviet Union, Vietnam, Germany, Australia, France and the United States (Suon, 2001).

Librarians and their collaborators have not always been so honourable. The compilers of the Soviet Literary Encyclopedia, for example, had been complicit in the falsification of the dates of death of writers murdered by the KGB (Shentalinsky, 1997: 221). Librarians, such as those 
in Czechoslovakia, have not only followed orders to remove books and journals from their collections but, in some cases, have done so with zeal.

Both in this censorial mode and in a way which affirms freedom and diversity, the library emerges as an agent for change. It is an agent for the construction of national identity through the identification, preservation and celebration of national documentary heritage, helping to create a national habitus. Through performance of their responsibility to provide access to information, libraries contribute to both the self-image of a community and how it operates. Though the acquisitive imperative, the library preserved recorded knowledge, and indeed consecrated it through selection and preservation. The preservation of important documents, the construction of great collections of manuscripts and books for a bishop or sovereign served to maintain their dominance by privileging cultural capital and reinforcing orthodoxy. By supporting the social order, it reinforced position and privilege. Even in a democratic context, libraries continue to serve this function, especially in the actualisation of national identity by national libraries. Thus libraries can be said to contribute to the nature of a community as well as the ways in which the community sees itself. A community which conceptualises itself as open cannot tolerate restrictions on access to information, unless of course it is practising a form of 'méconnaissance', a misrecognition and reconstrual of social and cultural practices (Mahar et al., 1990: 19-20).

Libraries, and public libraries in particular, support literacy and thus enable those who use them to maintain and extend their skills in reading and accessing information. Through presenting a range of information resources, libraries enable those who are interested to access different perspectives on social, political and economic issues and to research the background to matters of interest. Libraries can contribute to a group habitus. They contribute to "a person's own knowledge and understandings of the world, which makes a separate contribution to the reality of that world" (Bourdieu, 1986: 467). The dispositions which they support guide and limit the person's choices. Thus, the agency of libraries extends to facilitating the social trajectories of individuals and communities through access to information and its rôle as an institution for education.

However, there is also considerable evidence that libraries may be considered as instruments for the reproduction of social class and maintaining the dominance of the literate and educated. Through privileging certain cultural capital, libraries reject other capital. The necessary procedure of selecting that which is to be collected and made available by a library is a way of distinguishing cultural capital. Libraries thus exhibit symbolic violence, "the power to impose ... instruments of knowledge and (sic) expression of social reality" (Bourdieu, 1977: 115). By privileging the cultural capital favoured by the dominant class, libraries may thereby sustain that class. Far from facilitating social trajectories as the 'poor man's university', libraries may in fact inhibit those outside the dominant class from successfully negotiating such a trajectory.

\section{Cornerstones of liberty}

At the heart of this argument lies a syllogism which links good libraries to a healthy democracy. The first proposition is that libraries provide access to information and good libraries provide uninhibited access to information for all members of the community they serve. The second is that a healthy democracy depends on an informed and participative community. In other words, the effective operation of a democracy which is based upon 'the 
will of the people' demands information to guide that will and to enable informed consent. Thus, it is argued that good libraries help to foster a healthy democracy through supporting democratic process by providing uninhibited access to the information members of the community need to participate effectively in democratic processes. By extension, libraries can be viewed as carriers or vectors for spreading notions of freedom and democracy (Kranich, 2001).

It is in this sense that libraries have claimed for themselves the mantle of the 'cornerstones of liberty' (Kranich, 2001). The Government of Sweden has recognised the part that libraries can play in the furtherance and renewal of Swedish democracy by promoting a series of seminars on "Libraries and democracy" in 1999 (Byrne, 1999). That Government considered libraries to make a major contribution to civil society. But libraries or library-like activities can also be seen to be subversive, as has been argued about the so-called independent libraries established by dissidents in Cuba since 1999.

A 'good' library is, in this context, a library which meets the expectations of the Unesco Public Library Manifesto (IFLA/Unesco, 1994), not necessarily one which has the best collections, staff or technology. One of the key elements is the principle that the public library is open to all (Abid, 1996):

The rejection, in one go, of all forms of social discrimination confers on the public library an outstanding legal and social function in the promotion of equal opportunity.

The 1994 revision of the Manifesto considers the public library to be "a vital force in the promotion of basic human rights" including the rights expressed in Articles 19, 26 and 27 of the Universal Declaration (Niegaard, 1994). The emphasis in the first version on the part libraries can play in advancing human development was preserved but there is greater emphasis on its rôle in promoting the development of democracy.

Thus there is growing acceptance, at least in international librarianship, that libraries have a rôle in supporting democracy. Conversely, it might be argued that a healthy democracy supports good libraries: that their existence is a manifestation of well-founded democratic attitudes and behaviours. Indeed, it may be confirmed in the negative by noting that free and equal access to libraries is not evident in communities which do not treat members equally, in which people may be disenfranchised by race, gender or other difference. The importance of the commitment to intellectual freedom in relation to libraries substantially rests on such assertions.

\section{Libraries and the concerned intellectual}

But what of intellectuals? Their rôles in society have been much discussed. They have a particular agency in representing a society to itself. In the language of nations, it is intellectuals who frame the rhetoric, even if it is polemicists who inflame the masses.

In many ways, libraries preserve the tracks in the sand which record where intellectuals have journeyed. Their expressions, both formal and informal, are found in the books and journals, magazines and newspapers and other media collected and preserved by libraries. In this sense, the use of libraries may be little more than necromancy, or acquiring wisdom "by consulting the oracular dead" (Hare, 1859, cited in the OED). All libraries facilitate such 
communing but it is perhaps most marked in academic libraries which support the emblematic reference to key intellectuals by students in the pursuit of intellectual enlightenment.

Mass media pundits who similarly borrow authority from intellectual 'names' to justify their musings might certainly be accused of necromancy in the dictionary sense of "the pretended art of divination through communication with the dead" (Macquarienet, 2002). They tend to adopt the currently fashionable intellectuals to justify their own positions or to provide convenient stalking horses for ideas that they wish to condemn.

However, such gibes aside, libraries do fulfil a vital rôle for intellectuals by offering them the riches of previous thought and their interconnections, at least by implication through formed collections and ordered classifications. Intellectuals are able to explore both the wisdom and folly of their predecessors. By bringing together publications from many places and many times, libraries enable the intellectual to explore ideas and issues. Their explorations can enable intellectuals to connect disparate thoughts and to create new insights. The evidence necessary to provide a firm foundation for their insights can be found in collections of statistics and other documentation. They can apply conceptions from other cultures and situations to their own communities and environments. These processes lead to new areas of discourse among intellectuals and into the broader community as, for example, we have seen in Australia since the publication of Henry Reynolds' The other side of the frontier (Reynolds, 1981). Although he was not the first to document the cultural and material dispossession of Aboriginal peoples, nor the first to identify Aboriginal resistance to settler invasion, his work helped to galvanise the initiatives to achieve reconciliation between indigenous and other Australians. That work was grounded in the resources of libraries and archives.

Libraries are particularly valuable to intellectuals who are isolated from intellectual discourse by language, ideology, warfare, poverty or distance. They enable the intellectual to maintain contact with current discourse in other parts of the world and to explore earlier ideas. In such situations, they truly provide an intellectual 'life support system'. The destruction of libraries as an element of ethnic or cultural 'cleansing' removes those contextual support systems and hence weakens the position of intellectuals. Both the symbolic frame in which they operate and the resources on which they depend to extend their arguments are undermined so that they become voices in exile, even if physically remaining within their own country.

In the contested rôle of the concerned intellectual we acknowledge those who must question questioning. Perhaps this is highlighted nowhere more than in the position of "post colonial intellectuals" as discussed by Said, drawing on aspects of the work of Bourdieu (Williams, 2001). Whatever that "concerned intellectual” may be, their rôle is crucial to our societies but they must also be able to draw on and contribute to an evolving corpus of knowledge. Their place is contested with the term frequently used a badge of honour, presumably to distinguish them from 'unconcerned intellectuals'. In this purposeful sense, intellectuals must be "concerned" and libraries have a function in sustaining and feeding the fruits of their concerns.

To fulfil their aspect of this agency, it is imperative that libraries should provide uninhibited access to knowledge and information. They must "provide access to information, ideas and works of imagination in any medium and regardless of frontiers ... serve as gateways to knowledge, thought and culture ... offering their clients access to relevant resources and services without restriction and to opposing any form of censorship ... [with] no discrimination for any reason including race, national or ethnic origin, gender or sexual 
preference, age, disability, religion, or political beliefs” (IFLA, 2002). In achieving these goals, libraries extend well beyond the mechanistic functions which "provide access", "gateways", "resources and services" might imply to fulfil an aspiration to be reservoirs feeding intellectual discourse. It is a rôle which transcends and unifies the paradigms around which libraries have been construed and emphasises their value to humanity. 


\section{References}

Abid, A. (1996), Revision of the Unesco Public Library Manifesto, Proceedings of the 62nd IFLA Council and General Conference, Beijing, München, http://www.ifla.org.

American Library Association (1939), The library's bill of rights, American Library Association Bulletin, 33 pp. 60-61.

Anderson, F. (1970), Carnegie Corporation of New York In Encyclopedia of Library and Information Science, Vol. 4 (eds, Kent, A. and Lancour, H.), Marcel Dekker, New York, pp. 200-207.

Becker, J. (1998), Hungry ghosts: Mao's secret famine, Henry Holt, New York.

Beiner, R. (1999), Theorizing nationalism, SUNY Press, Albany.

Booth Fowler, R. (1978), Believing skeptics: American political intellectuals 19451964, Greenwood, Westport.

Bourdieu, P. (1977), Symbolic power In Identity and structure: issues in the sociology of education, (ed, Gleeson, D.), Nafferton, Driffield.

Bourdieu, P. (1986 [1979]), Distinction: a social critique of the judgment of taste, Routledge \& Kegan Paul, London.

Byrne, A. (1999), Libraries and democracy: keynote speech, The revolution begins in the library: National Seminar on Democracy, Stockholm, 4 November 1999, Swedish Library Association Journal.

Canovan, M. (1996), Nationhood and political theory, Edward Elgar, Cheltenham.

Canovan, M. (2000), Patriotism is not enough, British Journal of Political Science, 30 pp. 413-432.

Canovan, M. (2001), Sleeping dogs, prowling cats and soaring doves: three paradoxes in the political theory of nationhood, Political Studies, 49 pp. 203-215.

Frederiksen, C. and Bakken, F. (2000), Libraries in Kosova / Kosovo, IFLA/FAIFE, Copenhagen, http://www.faife.dk/.

Frederiksen, C. and Bakken, F. (2001), Alleged destructions of books in Serbian in Mitrovice/Kosovska Mitrovica, IFLA/FAIFE, Copenhagen, http://www.faife.dk/mitrorep.htm.

Geller, E. (1984), Forbidden books in American public libraries, 1876-1939: a study in cultural change, Greenwood Press, Westport.

Gunn, G. C. (1999), Timor Loro Sae: 500 years, Livros do Oriente, Macau.

Habermas, J. (1990), Citizenship and national identity In Between facts and norms: contributions to a discourse theory of law and democracy, (ed, Habermas, J.), MIT Press, Cambridge, pp. Appendix II. 
Hare (1859 [1827]), Guesses cited in OED Online (ed, Oxford English Dictionary), OUP, Oxford, pp. 174, http://dictionary.oed.com/.

Hobson, A. (1970), Great libraries, Weidenfeld and Nicholson, London.

IFLA (1963), Libraries in the world: a long-term programme for the International Federation of Library Associations, Nijhoff, The Hague.

IFLA (2002), The Glasgow Declaration on Libraries, Information Services and Intellectual Freedom (draft), IFLA, The Hague.

IFLA Section of Public Libraries (1973), Standards for public libraries, Verlag Dokumentation, Pullach.

IFLA Section of Public Libraries (2001), The public library service: IFLA/UNESCO guidelines for development, Saur, München.

IFLA/Unesco (1994), Public Library Manifesto, IFLA, The Hague.

Ignatieff, M. (1994), Blood and belonging: journeys into the new nationalism, Vintage, London.

Kanevskii, B. (1973), Library In Great Soviet Encyclopedia, Vol. 3, Macmillan, New York.

Kesting, J. G. (1985), Qumran and the quest of modern librarianship In Encyclopedia of Library and Information Science, Vol. 39, Supplement 4 (ed, Kent, A.), Marcel Dekker, New York, pp. 368-387.

Kranich, N. (ed.) (2001), Libraries \& democracy: the cornerstones of liberty, ALA, Chicago.

Macquarienet (2002) Macquarie Dictionary, http://www.macnet.mq.edu.au/.

Mahar, C., Harker, R. and Wilkes, C. (1990), The basic theoretical position In An introduction to the work of Pierre Bourdieu: the practice of theory, (eds, Harker, R., Mahar, C. and Wilkes, C.), Macmillan, London, pp. 1-25.

Miller, D. (1995), On nationality, OUP, Oxford.

Miller, E. (1988), Prince of librarians: the life and times of Antonio Panizzi of the British Museum, British Library, London.

Molholt, P. (1993), Libraries as bridges; librarians as builders In Libraries and the future: essays on the library in the twenty-first century, (ed, Lancaster, F.), Haworth, Binghampton, pp. 27.

Munford, W. A. (1976), A history of the Library Association, Library Association, London. 
National Archives of Australia, National Library of Australia, State Library of New South Wales and State Library of Victoria (2001), Belonging - A Century Celebrated, http://www.belonging.org/misc-pages/text.html.

National Library of Australia (2001) Treasures from the world's great libraries, http://www.nla.gov.au/worldtreasures/html/intro.html.

Nichols, S. G. and Smith, A. (2001), The evidence in hand: report of the Task Force on the Artifact in Library Collections, Council on Library and Information Resources, Washington, http://www.clir.org/pubs/reports/pub103/pub103.pdf.

Niegaard, H. (1994), UNESCO's 1994 Public Library Manifesto, Proceedings of the 60th IFLA Council and General Conference, München, http://www.ifla.org.

Panizzi, A. (1836), In Select Committee on the British Museum 1836 Minutes paragraph 4795 quoted by Miller 1988: 120.

Parekh, B. (1995), Politics of nationhood In Nationalism, ethnicity and cultural identity in Europe, (eds, von Benda-Beckmann, K. and Berkuyten, M.), European Research Centre on Migration and Ethnic Relations, Utrecht.

Reynolds, H. (1981), The other side of the frontier: an interpretation of the Aboriginal response to the invasion and settlement of Australia, James Cook University, Townsville.

Robbins, L. S. (1996), Censorship and the American library: the American Library Association's response to threats to intellectual freedom 1939-1969, Greenwood, Westport.

Said, E. (1984), Reflections on exile, Granta, 13 pp. 157-172.

Shentalinsky, V. (1997), The KGB's literary archive, Harvill, London.

State Lenin Library of the USSR (1987), The State Lenin Library of the USSR 18621987, [State Lenin Library of the USSR], [Moscow].

Steen, M. (2001), Precious little survives hammers of men who desecrated for God, Sydney Morning Herald, 5 December 2001, http://www.smh.com.au.

Sturges, P. and Rosenberg, D. (eds.) (1999), Disaster and after: the practicalities of information service in times of war and other catastrophes, Taylor Graham Publishing, London.

Suon, S. (2001), Cambodia Country Report: update on the National Library of Cambodia In 9th Conference of Directors of National Libraries of Asia and Oceania (CDNLAO) Meeting, CDNLAO.

Williams, P. (2001), Nothing in the post? Said and problem of post-colonial intellectuals In Edward Said, Vol. I (ed, Williams, P.), Sage, London, pp. 314-334.

World Health Organization (2002) Fact Sheet 2: the global HIV/AIDS epidemic, http://www-nt.who.int/whosis/statistics/factsheets_hiv_nurses/fact-sheet-2/index.html. 